\title{
Multivariate analysis of pathophysiological factors in reflux oesophagitis
}

\author{
G Cadiot, A Bruhat, D Rigaud, T Coste, A Vuagnat, Y Benyedder, T Vallot, \\ D Le Guludec, M Mignon
}

Department of Hepato-

Gastroenterology, Bichat-Claude Bernard Hospital, Paris, France

G Cadiot

A Bruhat

D Rigaud

Y Benyedder

T Vallot

M Mignon

\section{Department of} Hepato-

Gastroenterology, Avicenne Hospital, Bobigny, France

T Coste

INSERM U169, Villejuif, France A Vuagnat

Department of Nuclear Medicine,

Bichat-Claude

Bernard Hospital,

Paris, France

D Le Guludec

Correspondence to: Dr G Cadiot,

Service d'hépato-

gastroentérologie, Hôpital Bastroenterologie, Hopital rue Henri-Huchard, 75877

Accepted for publication 20 September 1996

\section{Abstract}

Background-Reflux oesophagitis is considered a multifactorial disease, but the respective roles of the main factors involved in its pathophysiology have not been clearly established.

Aims-To attempt to assign these roles by means of a multivariate logistic regression analysis of the main parameters associated with reflux oesophagitis.

Patients-Eighty seven patients with gastro-oesophageal reflux disease were studied: 41 without oesophagitis and 46 with reflux oesophagitis grade 1 to 3 .

Methods-(1) Monovariate comparison of patients' characteristics and of parameters derived from in hospital 24 hour oesophageal pH monitoring, oesophageal manometry, double isotope gastric emptying studies, and basal and pentagastrin stimulated gastric acid and pepsin output determinations, between patients with and without oesophagitis. (2) Multivariate logistic regression analysis including the parameters significant in the monovariate analysis.

Results-Among the 16 significant parameters from monovariate analysis, three significant independent parameters were identified by multivariate logistic regression analysis: number of refluxes lasting more than five minutes, reflecting oesophageal acid clearance $(p=0.002)$; basal lower oesophageal sphincter pressure $(p=0.008)$; and peak acid output $(p=0 \cdot 012)$. These three parameters were not correlated with each other. The multivariate model was highly discriminant (correct classification of $81.3 \%$ of the cases $(95 \%$ confidence intervals $0.723,0.903)$. Risk for oesophagitis increased as a function of the tercile threshold values of the three parameters. Odds ratios of the three parameters for oesophagitis risk were similar, regardless of whether they were calculated when the patients were compared as a function of oesophagitis grade or the presence or absence of oesophagitis.

Conclusion-This multivariate approach adds evidence that impaired oesophageal acid clearance and hypotonic lower oesophageal sphincter are the two major independent pathophysiological factors of oesophagitis, but also showed that the acid secretion level is an independent pathophysiological factor.

(Gut 1997; 40: 167-174)

Keywords: reflux oesophagitis, pathophysiology, multivariate analysis, oesophageal clearance, lower oesophageal sphincter, acid secretion.

When the antireflux barrier is impaired, permanently or transiently, gastro-oesophageal reflux may occur. The reasons why some patients with gastro-oesophageal reflux disease (GORD) develop reflux oesophagitis are not fully understood. ${ }^{1-4}$ For many authors, reflux oesophagitis can be regarded mainly as a primary motility disorder with disturbances of oesophageal motility and clearance, ${ }^{5-9}$ lower oesophageal sphincter (LOS) incompetence, ${ }^{10}{ }^{11}$ and, for some authors, delay in gastric emptying. ${ }^{12}$ However, many other factors could contribute to the creation of oesophageal mucosal erosions such as the toxicity of the refluxate, ${ }^{1314}$ which depends on the characteristics of the gastric juice, and the oesophageal mucosal resistance. ${ }^{15}{ }^{16}$ Furthermore, the respective part played by each pathophysiological factor in the creation of oesophageal erosions is unknown. Although reflux oesophagitis seems to be a multifactorial disease, many studies have only considered each of its potential pathophysiological factors, separately. Few studies have considered the association of several pathophysiological factors of oesophagitis. ${ }^{17-23}$ None used a multivariate model including the main factors differentiating between GORD patients with and without oesophagitis.

The aim of this study was to evaluate the respective roles of the main factors involved in the pathophysiology of reflux oesophagitis by means of multivariate logistic regression analysis. The studied parameters were patients' characteristics and parameters derived from 24 hour oesophageal $\mathrm{pH}$ monitoring, standard oesophageal manometry, double isotope gastric emptying studies, and basal and pentagastrin stimulated acid and pepsin secretion determinations. A monovariate comparison of these parameters was first carried out in two groups of GORD patients, with or without reflux oesophagitis, then the significant parameters were included in the multivariate analysis. Odds ratios of the identified independent parameters for oesophagitis risk were determined. 


\section{Methods}

PATIENTS

Outpatients suffering from GORD were prospectively recruited by two of us (TC, MM). Patients who had undergone upper digestive endoscopy performed by three of us (GC, TC, TV) and in hospital 24 hour oesophageal $\mathrm{pH}$ monitoring could be included in the study when the following inclusion and exclusion criteria were fulfilled. The inclusion criteria were: (1) typical symptoms of GORD - that is, heartburn, regurgitation or both, for more than six months - or atypical GORD related symptoms, such as chronic bronchopulmonary symptoms, chronic laryngitis or non-cardiac chest pain, and (2) excessive oesophageal acid exposure on in hospital 24 hour oesophageal $\mathrm{pH}$ monitoring that is, $>4 \cdot 2 \%$ of reflux time at $\mathrm{pH}<4$ on 24 hour recording or $>6.3 \%$ in the upright position, or $>1.2 \%$ in the supine position, ${ }^{24}$ or all three. Exclusion criteria were: (1) previous gastric or oesophageal surgery; (2) diabetes mellitus; (3) progressive systemic sclerosis, Raynaud's syndrome and other vascular collagen diseases; (4) neurological disorders; (5) Zollinger-Ellison syndrome; and (6) complicated oesophagitis that is, oesophageal ulcer or stenosis and Barrett's oesophagus ( $>3 \mathrm{~cm}$ of columnar cell lined oesophagus). Patients who gave their informed consent and underwent oesophageal manometry, double isotope gastric emptying study, and basal and pentagastrin stimulated gastric acid and pepsin output determinations were included. The study was conducted in accordance with the Helsinki Declaration.

\section{STUDY DESIGN}

\section{Endoscopy}

Upper digestive tract endoscopy was performed routinely without sedation using Olympus endoscopes. The absence of oesophagitis was defined as the absence of erosions (no oesophagitis group). Oesophagitis was graded as follows: grade 1: erosion(s) involving only a single longitudinal oesophageal fold; grade 2: non-circumferential mutiple erosions involving more than one longitudinal fold with or without confluence; grade 3: circumferential erosions. ${ }^{25}$ Hiatal hernia, defined as a distance between the diaphragmatic hiatus and the gastro-oesophageal junction $>2 \mathrm{~cm}$, was diagnosed endoscopically. Helicobacter pylori status was not assessed.

\section{In hospital 24 hour oesophageal $p H$ monitoring}

All studies were performed with a glass $\mathrm{pH}$ electrode (Ingold 10-4403022, diameter $3 \cdot 8$ $\mathrm{mm}$ ) connected to a portable digital recorder (Digitrapper, Synectics Medical). Before each recording, the $\mathrm{pH}$ electrode was standardised against buffer solutions at $\mathrm{pH} 7 \cdot 0,4 \cdot 0$, and $1 \cdot 0$. The $\mathrm{pH}$ probe was inserted through the nose and its tip was positioned $5 \mathrm{~cm}$ above the gastro-oesophageal junction, identified $\mathrm{pH}$ metrically and not manometrically. All the patients were prescribed the same standardised diet: $2085 \mathrm{kcal} / 24 \mathrm{~h}, 15 \cdot 8 \%$ protein, $36 \cdot 6 \%$ fat, and $47 \cdot 6 \%$ carbohydrates with meals at 7 00-7 30, 12 00-12 30, 18 30-19 00. Patients recorded the time of food or fluid consumption and posture changes on a diary card. Data were analysed on an IBM PC (software: Esogram/ Gastrogram 9822, version 5.09, Gastrosoft). The following variables were recorded during the 24 hour period and during the upright and supine periods: number of refluxes lasting $>5$ minutes (NR5) at $\mathrm{pH}<4$, percentage of reflux time at $\mathrm{pH}<4$, number of refluxes at $\mathrm{pH}<4$, and duration of the longest reflux at $\mathrm{pH}<4$.

\section{Oesophageal manometry}

After an overnight fast, oesophageal manometry was performed using a 4 catheter water perfused tube (external diameter, $5 \mathrm{~mm}$ ) connected to an Arndorfer hydrocapillary pump. The distal side openings on the catheters were staggered radially at $90^{\circ}$ intervals and were spaced $5 \mathrm{~cm}$ apart. The station pull through technique was used to determine the basal LOS pressure (LOSP) at the pressure inversion point on each catheter. Intervals between steps were $20-30$ seconds. The mean of four values obtained in each patient was calculated. The amplitudes of at least 10 oesophageal waves were measured $5 \mathrm{~cm}$ and 10 $\mathrm{cm}$ above the LOS after swallowing $5 \mathrm{ml}$ of water at 20 to 30 second intervals and the means of these wave amplitudes were calculated. The percentage of completely propagated oesophageal waves between $10 \mathrm{~cm}$ and $5 \mathrm{~cm}$ above the LOS was determined.

\section{Double isotope gastric emptying study}

Gastric emptying of both solid and liquid phases of a meal was studied as previously described. ${ }^{26}$ Briefly, after an overnight fast, a double labelled test meal of $450 \mathrm{kcal}$ was eaten in less than 15 minutes at 1100 . The meal contained $21 \mathrm{~g}$ of protein, $23 \mathrm{~g}$ of fat, and $40 \mathrm{~g}$ of carbohydrate, in a final volume of 400 $\mathrm{ml}$. The liquid phase of the meal was labelled by $100 \mu \mathrm{Ci}$ of [ $\left.{ }^{111} \mathrm{In}\right] \mathrm{DTPA}$ diluted with tepid water $(220 \mathrm{ml})$ and the solid phase with $1 \mathrm{mCi}$ of ${ }^{99} \mathrm{~m}$ Tc-ovalbumin mixed into eggs. The 237 $\mathrm{keV}( \pm 20 \%)$ peak for gamma emissions was selected as the indium 'window' and the 140 $\mathrm{keV}( \pm 10 \%)$ peak as the technetium 'window'. An Acti-gamma camera (CGR, SophaMedical, Paris, France) was used, connected to a Digital Equipment (Sismis III, SophaMedical). The region corresponding to the stomach was determined on both anterior and posterior images. Successive one minute anterior and one minute posterior images were collected at 10 minute intervals for 200 minutes, with the subject in an upright position. Results for both solids and liquids are expressed as time elapsed until $50 \%$ emptying (emptying half time) had been achieved and as lag time ( $\mathrm{min}$ ) for emptying solids.

Gastric acid and pepsin output determinations Tests were performed after an overnight fast as previously described. ${ }^{27}$ Briefly, a nasogastric 
tube was placed in the stomach and its position checked by the water recovery test, while the patient lay in a semirecumbent position. The gastric juice was collected by gentle manual aspiration and pooled in 15 minute samples during the basal state for 75 minutes and in response to pentagastrin $(6 \mu \mathrm{g} / \mathrm{kg}$ intramuscularly) for 60 minutes. The first 15 minute sample was discarded. Subsequent 15 minute samples were stored at $4^{\circ} \mathrm{C}$ immediately after collection. The volume of each sample was measured. Acidity was determined by titration up to $\mathrm{pH} 7 \cdot 0$ and proteolytic activity (pepsin) by an automated method using human haemoglobin as the substrate.$^{28}$ Basal hourly acid and pepsin outputs were calculated. Peak acid (PAO) and pepsin outputs in response to pentagastrin were calculated as twice the sum of the two consecutive 15 minute samples having the highest acid or pepsin outputs. Gastric acid outputs are expressed as $\mathrm{mmol} / \mathrm{h}$ and pepsin outputs as pepsin units/h.

\section{STATISTICS}

Results are expressed as medians and ranges. Monovariate comparisons between the two groups of patients, with and without oesophagitis, were made using the Kruskal-Wallis test or the Mann-Whitney $U$ test for quantitative parameters and the $\chi^{2}$ test for qualitative parameters with Yates's correction whenever relevant. Correlations between parameters were measured by the Spearman rank correlation coefficient. Statistical significance was set at $\mathrm{p}<0.05$. Parameters significant according to the monovariate analysis between patients with and without oesophagitis were included in a multivariate logistic regression analysis. Independent significant parameters were

TABLE I Characteristics of the two groups of GORD patients

\begin{tabular}{llll}
\hline Parameter & $\begin{array}{l}\text { No oesophagitis } \\
(n=41)\end{array}$ & $\begin{array}{l}\text { Oesophagitis } \\
(n=46)\end{array}$ & $p$ Value \\
\hline Age (y) median (range) & $47(24-71)$ & $58(26-81)$ & $0 \cdot 025$ \\
Women/men & $22 / 19$ & $13 / 33$ & $0 \cdot 015$ \\
BMI $\left(\mathrm{kg} / \mathrm{m}^{2}\right)$ median (range) & $24 \cdot 0(16 \cdot 3-31 \cdot 0)$ & $25 \cdot 9(20 \cdot 7-35 \cdot 4)$ & 0.005 \\
Hiatal hernia & 18 & 34 & 0.004
\end{tabular}

BMI: body mass index: weight/height ${ }^{2}$. $p$ Values for age and BMI were determined using MannWhitney $U$ test, and for sex and hiatal hernia with the $\chi^{2}$ test.

TABLE II Oesophageal $p H$ monitoring data in the two groups of GORD patients

\begin{tabular}{|c|c|c|c|}
\hline Parameter & $\begin{array}{l}\text { No oesophagitis ( } n=41) \\
\text { median (range) }\end{array}$ & $\begin{array}{l}\text { Oesophagitis ( } n=46) \\
\text { median (range) }\end{array}$ & $p$ Value* \\
\hline \multicolumn{4}{|l|}{ NR5 } \\
\hline Total & $4 \cdot 0(0 \cdot 0-19 \cdot 0)$ & $8 \cdot 0(0 \cdot 0-30 \cdot 0)$ & 0.0002 \\
\hline Upright & $3.0(0.0-15 \cdot 0)$ & $4 \cdot 0(0 \cdot 0-17 \cdot 0)$ & 0.039 \\
\hline Supine & $1.0(0.0-16 \cdot 0)$ & $2 \cdot 3(0 \cdot 0-26 \cdot 0)$ & $0 \cdot 130$ \\
\hline \multicolumn{4}{|c|}{ Reflux time (\%) } \\
\hline Total & $6 \cdot 9(1 \cdot 4-44 \cdot 0)$ & $12 \cdot 2(3 \cdot 6-51 \cdot 5)$ & 0.0009 \\
\hline Upright & $9 \cdot 9(1 \cdot 3-27 \cdot 2)$ & $12.9(3.3-68 \cdot 0)$ & 0.030 \\
\hline Supine & $6 \cdot 2(0 \cdot 1-62 \cdot 8)$ & $8 \cdot 0(0 \cdot 2-65 \cdot 4)$ & $0 \cdot 240$ \\
\hline \multicolumn{4}{|c|}{ No of reflux episodes } \\
\hline Total & $46 \cdot 0(7 \cdot 0-157 \cdot 0)$ & $64 \cdot 0(13 \cdot 0-216 \cdot 0)$ & 0.030 \\
\hline Upright & $31 \cdot 0(2 \cdot 0-121 \cdot 0)$ & $49 \cdot 5(8 \cdot 0-150 \cdot 0)$ & 0.010 \\
\hline Supine & $8 \cdot 0(2 \cdot 0-42 \cdot 0)$ & $13.0(2 \cdot 0-68 \cdot 0)$ & 0.071 \\
\hline \multicolumn{4}{|c|}{ Longest reflux (min) } \\
\hline Total & $31 \cdot 0(4 \cdot 0-208 \cdot 0)$ & $31 \cdot 0(2 \cdot 0-128 \cdot 0)$ & 0.440 \\
\hline Upright & $13 \cdot 0(1 \cdot 0-71 \cdot 0)$ & $19 \cdot 5(2 \cdot 0-128 \cdot 0)$ & 0.053 \\
\hline Supine & $34 \cdot 0(1 \cdot 0-208 \cdot 0)$ & $20.5(1.0-204 \cdot 0)$ & 0.430 \\
\hline
\end{tabular}

*Mann-Whitney $U$ test. Total: during the 24 hour monitoring period. Upright: during the upright period monitoring. Supine: during the supine monitoring period. identified using an ascending selection procedure (Proc Logistic, SAS 6.08, Cary, NC, USA). The final model included only those parameters with a $\mathrm{p}$ value $<0.05$. Threshold values of the independent significant parameters were determined according to the terciles of each parameter. Odds ratios of these threshold values were calculated for oesophagitis risk. The selected parameters were also included in a multivariate logistic regression analysis comparing the patients as a function of the grade of oesophagitis.

\section{Results}

Eighty seven GORD patients were studied: 41 had no oesophageal erosion (no oesophagitis group); 46 had oesophageal erosions (oesophagitis group). In this second group, 10 patients $(22 \%)$ had grade 1 oesophagitis, 30 patients $(65 \%)$ had grade 2 oesophagitis, and six patients $(13 \%)$ had grade 3 oesophagitis.

\section{MONOVARIATE ANALYSIS}

\section{Patients' characteristics (Table I)}

Compared with patients without oesophagitis, patients with oesophagitis were significantly older $(p=0.025)$, had a significantly higher body mass index $(p=0.005)$, were more often men $(p=0.015)$, and more of them had a hiatal hernia $(p=0.004)$.

\section{In hospital 24 hour oesophageal pH monitoring (Table II)}

Among oesophageal 24 hour $\mathrm{pH}$ monitoring data, the most relevant factor was NR5; its median was two times higher in the group with oesophagitis than in the group without $(p=0 \cdot 0002)$. NR5 also differed significantly by group when patients were compared according to their grade of oesophagitis ( $p=0.002)$ (Fig 1), and there was a significant linear correlation between NR5 and the grade of oesophagitis $(r=0.41, \mathrm{p}<0.001)$. The difference between NR5 values for patients with hiatal hernia and

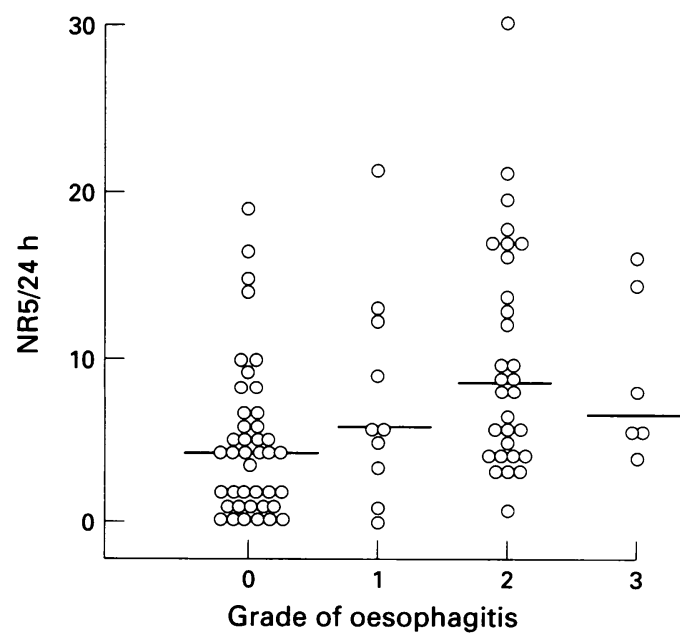

Figure 1: Individual numbers of refluxes lasting $>5$ minutes (NR5) during the 24 hour oesophageal $p H$ recording as a function of the grade of oesophagitis. ${ }^{25}$ Bars indicate medians. $p=0.002$ (Kruskal-Wallis test). 
TABLE III Oesophageal and gastric motility data in the two groups of GORD patients

\begin{tabular}{lccl}
\hline Parameter & $\begin{array}{l}\text { No oesophagitis }(n=41) \\
\text { median (range) }\end{array}$ & $\begin{array}{l}\text { Oesophagitis }(n=46) \\
\text { median (range) }\end{array}$ & $p$ Value* \\
\hline LOSP (mm Hg) & $18 \cdot 0(4 \cdot 0-33 \cdot 0)$ & $11 \cdot 8(4 \cdot 5-25 \cdot 0)$ & $0 \cdot 0008$ \\
Ampl $5(\mathrm{~mm} \mathrm{Hg})$ & $87 \cdot 0(36 \cdot 0-183 \cdot 0)$ & $73 \cdot 0(20 \cdot 0-195 \cdot 0)$ & $0 \cdot 150$ \\
Ampl 10 (mm Hg) & $79 \cdot 0(37 \cdot 0-162 \cdot 0)$ & $63 \cdot 0(10 \cdot 0-161 \cdot 0)$ & $0 \cdot 050$ \\
Propagation (\%) & $100 \cdot 0(80 \cdot 0-100 \cdot 0)$ & $100 \cdot 0(80 \cdot 0-100 \cdot 0)$ & $0 \cdot 480$ \\
$\mathrm{~T}_{1 / 2}$ solids (min) & $120 \cdot 0(60 \cdot 0-195 \cdot 0)$ & $105 \cdot 0(45 \cdot 0-180 \cdot 0)$ & $0 \cdot 280$ \\
$\mathrm{~T}_{1 / 2}$ liquids (min) & $75 \cdot 0(15 \cdot 0-150 \cdot 0)$ & $75 \cdot 0(30 \cdot 0-165 \cdot 0)$ & $0 \cdot 670$ \\
Lag time (min) & $18 \cdot 2(0 \cdot 0-137 \cdot 0)$ & $16 \cdot 1(0 \cdot 0-150 \cdot 4)$ & $0 \cdot 840$ \\
\hline
\end{tabular}

*Mann-Whitney U test. Ampl 5 and 10: oesophageal wave amplitude measured 5 and $10 \mathrm{~cm}$ above the LOS. $T_{1 / 2}$ : gastric emptying half time. Lag time: lag time for gastric emptying of solids

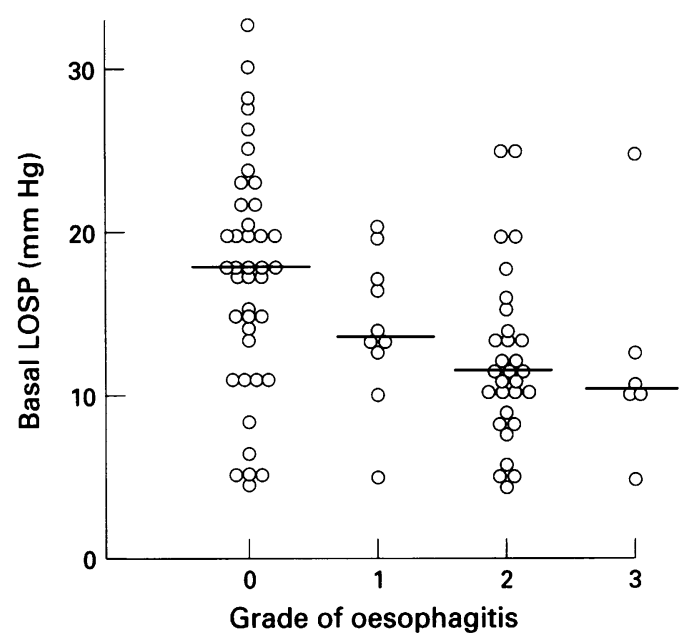

Figure 2: Individual values of the basal lower oesophageal sphincter pressure (LOSP) as a function of the grade of oesophagitis. ${ }^{25}$ Bars indicate medians. $p=0.005$ (KruskalWallis test).

those without hiatal hernia did not reach statistical significance $(p=0 \cdot 06)$. The median percentage of total reflux time (at $\mathrm{pH}<4$ ) was higher in the oesophagitis group than in the no oesophagitis group $(+76 \cdot 8 \%)(p=0 \cdot 0009)$. The percentage of total reflux time was significantly correlated with NR5 $(r=0.90, \mathrm{p}<0.0001)$. Significantly higher numbers of reflux episodes were recorded in the oesophagitis group. The $\mathrm{pH}$ monitoring data also differed significantly between the two groups in the upright position but not in the supine position.

\section{Oesophageal manometry (Table III)}

Basal median LOSP in patients with oesophagitis was $34.4 \%$ lower than in patients without oesophagitis $(p=0.0008)$. Furthermore, LOSP also differed significantly between groups when patients were compared according to their grade of oesophagitis $(p=0.005)$ (Fig 2). There was a weak but significant linear correlation between basal LOSP and the grade of oesophagitis $(r=-0.38, \mathrm{p}<0.001)$. The

TABLE IV Gastric acid and pepsin outputs in the two groups of GORD patients

\begin{tabular}{lccc}
\hline Output & $\begin{array}{l}\text { No oesophagitis }(n=41) \\
\text { median (range) }\end{array}$ & $\begin{array}{l}\text { Oesophagitis }(n=46) \\
\text { median (range) }\end{array}$ & $p$ Value $^{*}$ \\
\hline Basal acid (mmol/h) & $2 \cdot 2(0 \cdot 0-25 \cdot 7)$ & $4.9(0 \cdot 0-19 \cdot 8)$ & 0.033 \\
Peak acid (mmol/h) & $27 \cdot 0(8 \cdot 4-55 \cdot 3)$ & $34.0(5 \cdot 8-75 \cdot 9)$ & 0.007 \\
Basal pepsin (PU/h) & $200 \cdot 0(0 \cdot 0-1450 \cdot 0)$ & $371.0(0 \cdot 0-1205 \cdot 0)$ & 0.009 \\
Peak pepsin (PU/h) & $790 \cdot 0(145 \cdot 0-2270 \cdot 0)$ & $1068 \cdot 0(180 \cdot 0-2906 \cdot 0)$ & 0.020 \\
\hline
\end{tabular}

^Mann-Whitney U test. PU: pepsin unit. median amplitude of oesophageal waves measured $10 \mathrm{~cm}$ above LOS was $20.3 \%$ lower in patients with oesophagitis $(p=0 \cdot 05)$. The percentage of completely propagated oesophageal waves did not differ significantly between the two groups. In 12 patients with oesophagitis and 15 patients without oesophagitis, $90 \%$ or less of the oesophageal waves were completely propagated (NS).

Double isotope gastric emptying study (Table III) Median gastric emptying half time of solids and liquids and lag time for emptying of solids were comparable for the two groups.

\section{Gastric acid and pepsin output determinations (Table IV)}

Median PAO was $25.9 \%$ higher in oesophagitis patients compared with patients without oesophagitis $(p=0.007)$. When comparing the patients according to their grade of oesophagitis, PAO tended towards significance $(p=0.061)$ (data not shown). There was a slight but significant linear correlation between PAO and the grade of oesophagitis $(r=0.28$, $p<0 \cdot 010)$. Eight $(17 \cdot 4 \%)$ oesophagitis patients had PAO values above the mean PAO+2 SD of the non oesophagitis group - that is, 51 $\mathrm{mmol} / \mathrm{h}$. The percentage of patients with PAO $>51 \mathrm{mmol} / \mathrm{h}$ increased significantly with the grade of oesophagitis $(\mathrm{p}=0.016)$ - that is, $2 \cdot 4 \%, 0 \%, 20 \%$, and $33 \%$ of the patients with no oesophagitis, grade 1 , grade 2 , and grade 3 oesophagitis, respectively. Median basal acid output, basal pepsin output, and peak pepsin output were higher in the patients with oesophagitis than in those without oesophagitis, $+122.7 \%(p=0.033),+85.5 \%(p=0.009)$, and $+35 \cdot 2 \%(p=0.020)$, respectively.

MULTIVARIATE LOGISTIC REGRESSION ANALYSIS The 16 significant parameters identified by monovariate analysis were included in the multivariate logistic regression analysis. These factors were: age, sex, body mass index, presence of hiatal hernia, NR5 during the 24 hour period and during the upright period, percentage of reflux time during the 24 hour period and during the upright period, number of reflux episodes during the 24 hour period and during the upright period, basal LOSP, amplitude of contraction waves measured $10 \mathrm{~cm}$ above LOS,

TABLE V Multivariate logistic regression analysis between GORD patients with or without oesophagitis

\begin{tabular}{lrlll}
\hline Parameters & Estimate & $\begin{array}{l}\text { Odds } \\
\text { ratio }\end{array}$ & $\begin{array}{l}\text { Odds ratio } \\
95 \% \text { CI }\end{array}$ & $p$ Value \\
\hline NR5 & 0.1539 & 1.166 & $1.057,1.287$ & 0.002 \\
LOSP & -0.1167 & 0.890 & $0.816,0.970$ & 0.008 \\
PAO & 0.0508 & 1.052 & $1.011,1.095$ & 0.012 \\
Intercept & -0.8944 & 0.409 & $0.060,2.767$ & 0.359
\end{tabular}

The multivariate analysis included the 16 significant parameters identified by monovariate comparison between the two groups of GORD patients. *: with a one point increment. The odds ratio of each parameter was adjusted to the other two parameters. $\mathrm{CI}=$ confidence intervals. The model correctly classified the patients (no oesophagitis or oesophagitis) in $81 \cdot 3 \%$ of the cases ( $95 \%$ CI: $0.723,0.903$ ). 
TABLE VI Spearman correlation analysis between the three independent parameters

\begin{tabular}{lll}
\hline Parameters & $\mathrm{r}$ & $p$ Value \\
\hline NR5/LOSP & -0.164 & $>0 \cdot 10$ \\
NR5/PAO & $0 \cdot 109$ & $>0 \cdot 10$ \\
LOSP/PAO & -0.147 & $>0.10$ \\
\hline
\end{tabular}

basal acid output, PAO, basal pepsin output, and peak pepsin output. The multivariate logistic regression analysis identified three independent factors that contribute significantly to differentiating between patients with and without oesophagitis - that is, NR5 $(p=0.002)$, basal LOSP $(p=0.008)$, and PAO $(p=0.012)$ (Table V). Body mass index and male sex had adjusted $\mathrm{p}$ values tending towards significance, $p=0.062$ and $p=0.067$, respectively. Other parameters had adjusted $\mathrm{p}$ values above $0 \cdot 14$.

The model, $-0 \cdot 8944+0 \cdot 1539 \times$ NR5 $-0 \cdot 1167$ $\times$ LOSP $+0 \cdot 0508 \times$ PAO, correctly classified patients as having oesophagitis or not in $81.3 \%$ of the cases ( $95 \%$ confidence intervals: 0.723 , 0.903 ). This model fits our data very well (Hosmer and Lemeshow goodness of fit test) with a non-significant $\mathrm{p}$ value of 0.98 .

The absence of correlation between NR5, LOSP, and PAO was determined by Spearman rank correlation analysis (Table VI).

ODDS RATIOS OF NR5, LOSP, AND PAO FOR OESOPHAGITIS RISK

Odds ratios, with each parameter being adjusted at constant level to the other two parameters, were calculated with a one point increment for NR5, LOSP, and PAO, and are given in Table $\mathrm{V}$.

The impact on the risk for oesophagitis of different thresholds of these three independent parameters, determined according to terciles, are indicated in Table VII. Compared with the parameter thresholds associated with the lowest oesophagitis risk - that is, NR $5<4 / 24 \mathrm{~h}$, LOSP $\geq 18 \mathrm{~mm} \mathrm{Hg}$, and PAO $<25 \mathrm{mmol} / \mathrm{h}$, respective odds ratios of the other parameter thresholds were significantly higher, with the exception of the parameter threshold $4 \leq \mathrm{NR} 5$ $<8 / 24 \mathrm{~h}(p=0.081)$. Because of the small numbers of patients, the determination of adjusted odds ratios for the combination of the parameter thresholds was not possible.

Odds ratios of NR5, basal LOSP, and PAO, calculated when the patients were divided into four groups as a function of oesophagitis grade (no oesophagitis, grade 1 , grade 2 , and grade 3 ) were very similar to the values calculated when the patients were divided into two groups, with and without oesophagitis (Table V). Odds ratios $(95 \% \mathrm{CI})$ calculated as a function of the oesophagitis grade were: $1.127(1.048,1.213)$ for NR5, $0.887(0.822,0.957)$ for basal LOSP, and $1.047(1.015,1.081)$ for PAO.

\section{Discussion}

The reasons why some GORD patients develop reflux oesophagitis remain unclear. As many parameters differentiate between GORD patients with and without oesophagitis, it is
TABLE VII Risk for oesophagitis according to different thresholds of NR5, LOSP, and PAO

\begin{tabular}{llll}
\hline Parameter thresholds & $\begin{array}{l}\text { Odds } \\
\text { ratio }\end{array}$ & $\begin{array}{l}\text { Odds ratio } \\
95 \% \text { CI }\end{array}$ & p Value \\
\hline NR5 $<4 / 24 \mathrm{~h}$ & 1.00 & - & - \\
$4 \leq \mathrm{NR} 5<8 / 24 \mathrm{~h}$ & $2 \cdot 76$ & $0 \cdot 88,8.59$ & 0.081 \\
NR5 $\geq 8 / 24 \mathrm{~h}$ & 6.86 & $2 \cdot 15,21.91$ & 0.001 \\
LOSP $\geq 18 \mathrm{~mm} \mathrm{Hg}$ & 1.00 & - & - \\
$11 \cdot 8 \leq \mathrm{LOSP}<18 \mathrm{~mm} \mathrm{Hg}$ & 4.58 & $1.44,14.57$ & 0.010 \\
LOSP $<11.8 \mathrm{~mm} \mathrm{Hg}$ & 6.32 & $2 \cdot 11,18.97$ & 0.001 \\
PAO $<25 \mathrm{mmol} / \mathrm{h}$ & 1.00 & - & - \\
$25 \leq \mathrm{PAO}<36 \mathrm{mmol} / \mathrm{h}$ & 3.12 & $1.04,9.33$ & 0.042 \\
PAO $\geq 36 \mathrm{mmol} / \mathrm{h}$ & 4.50 & $1.46,13.89$ & 0.009 \\
\hline
\end{tabular}

Thresholds were determined according to the terciles of each parameter.

generally accepted that the pathogenesis of reflux oesophagitis is multifactorial. ${ }^{1-4}$ In this study, most of the known parameters involved in the pathophysiology of reflux oesophagitis were investigated in each patient. To identify which factors independently differentiate these patients and to increase our understanding of the pathophysiology of reflux oesophagitis, we undertook a multivariate logistic regression analysis of the main known parameters that distinguished between GORD patients with and without oesophagitis after monovariate analysis.

The multivariate analysis showed that three independent parameters were significantly associated with oesophagitis - that is, NR5, LOSP, and PAO. These three parameters were not correlated with each other (Table VI). The odds ratio of each parameter for oesophagitis risk was calculated and the cumulative effect of these parameters on oesophagitis risk was established using the multivariate model. Our model was highly discriminant, as it correctly classified the patients into the two groups with and without oesophagitis - in $81.3 \%$ of the cases. Furthermore, its goodness of fit with our data was very high. These findings seem relevant because the oesophagitis risk associated with different thresholds of NR5, LOSP, and PAO increased with the increase in the threshold values of the three parameters (Table VII). This finding suggests a continuous effect of each parameter on oesophagitis risk. Furthermore, when the patients were compared as a function of the oesophagitis grade, NR5 and LOSP differed significantly (Figs 1 and 2), but PAO only tended towards significance $(p=0.061)$. A significant linear correlation was also found between the values of NR5, LOSP, and PAO and the grade of oesophagitis. Finally, odds ratios calculated as a function of the oesophagitis grade (four groups) were very similar to those calculated as a function of the absence or presence of oesophagitis (two groups).

Do these statistical findings have pathophysiological significance? Many studies have shown, as we did, that NR5 was higher in GORD patients with reflux oesophagitis than in those without oesophagitis, ${ }^{17} 232429-33$ and also that NR5 increased with the oesophagitis grade. ${ }^{32-34} \mathrm{NR5}$ is a marker of both oesophageal acid clearance and the amount of acid that refluxes, and was highly significantly correlated with the total percentage of reflux 
time ${ }^{172429}$ ( $r=0.90$ in our study). Although the percentage of total reflux time was highly significant after monovariate analysis (Table II), it was not identified as such by the multivariate analysis, probably because this parameter, unlike NR5, does not give information about oesophageal acid clearance. This also suggests that if acid exposure was an important factor of oesophagitis, independent from oesophageal acid clearance, the percentage of total reflux time would have been identified by the multivariate analysis. However, considering the high correlation between the percentage of total reflux time and NR5, we cannot exclude that the multivariate analysis underestimated the role of acid exposure. Using different methods, it has been shown that oesophageal acid clearance is impaired in reflux oesophagitis and is considered an important pathophysiological factor in reflux oesophagitis. $^{5-8} 17$ 30 35-43 Therefore, our study, using a multivariate approach, confirmed that impairment of oesophageal acid clearance is the main determinant of reflux oesophagitis.

Recent data showed the role of hiatal hernia in clearance impairment in patients with oesophagitis. ${ }^{43-45}$ However, the presence of a hiatal hernia, which was highly associated with reflux oesophagitis according to our monovariate analysis, was not identified as such in the multivariate model. NR5 had a non-significant tendency to be higher in patients with hiatal hernia than in patients without hiatal hernia and the only studied parameter reflecting oesophageal acid clearance (amplitude of the oesophageal waves measured $10 \mathrm{~cm}$ above LOS) that differed significantly between the two groups of GORD patients after monovariate analysis was not identified in the multivariate model. Therefore, our study does not allow us to speculate on the mechanisms of oesophageal acid clearance impairment in patients with oesophagitis.

LOS is a major factor in gastro-oesophageal competence which, in turn, is a major determinant of reflux oesophagitis. ${ }^{1-4} 6$ However, the pathophysiological significance of the basal LOSP value remains uncertain. Indeed, although it has been clearly determined that very low basal LOSP values are implicated in the pathophysiology of severe oesophagitis, many GORD patients with moderate oesophagitis have normal basal LOSP values. $^{1011} 19324647$ Most of the gastrooesophageal refluxes occur during transient LOS relaxations in GORD patients. ${ }^{101148}$ Furthermore, there is considerable overlap of basal LOSP values of individual GORD patients with and without oesophagitis and normal controls. Our study showed that two thirds of the patients had basal LOSP values over $11.8 \mathrm{~mm} \mathrm{Hg}$ (normal values). However, oesophagitis risk was clearly increased when basal LOSP values were below $18 \mathrm{~mm} \mathrm{Hg}$. This effect was much more significant for values below $11.8 \mathrm{~mm} \mathrm{Hg}$. Are these findings a cause or a consequence of oesophagitis? 1-4 $^{-9} 93749$ The results of our study do not allow us to resolve this question.
PAO reflects the acid secretory status of the patients. Although conflicting results have been reported concerning the relation between gastric acid secretion and reflux oesophagitis, ${ }^{1314} 19213150$ our multivariate model showed that PAO was also an independent factor associated with reflux oesophagitis. When comparing GORD patients with and without oesophagitis, PAO differed significantly (Table IV). Furthermore, there was a dose dependent increase in odds ratios as a function of the PAO values (Table VII). However, the correlation between PAO and the grade of oesophagitis was poor $(r=0 \cdot 28$, $\mathrm{p}<0.010)$ and PAO only tended towards significance when patients were compared as a function of their grade of oesophagitis $(p=0.061)$. Nevertheless, the percentage of patients with very high PAO values increased significantly with the grade of oesophagitis. Many studies have shown, after monovariate comparison, that PAO, maximal acid output, and the percentage of patients with acid hypersecretion were not significantly higher in GORD patients with oesophagitis compared with those without oesophagitis. ${ }^{13} 1421$ Therefore, many authors do not think that the composition of gastric juice in itself is a factor contributing to oesophagitis in GORD patients. However, many arguments suggest that the level of gastric acid secretion, which is a determinant of the composition of the refluxate, influences oesophagitis risk. Firstly, one of the most important arguments is the efficacy of gastric acid antisecretory drugs, which do not modify motility parameters, to promote oesophagitis healing. ${ }^{37}{ }^{51}$ Their effect depends on the level of acid reduction. ${ }^{50-53}$ Secondly, in Zollinger-Ellison syndrome, a chronic condition of acid hypersecretion, reflux oesophagitis is very common, ${ }^{54} 55$ the absence of significant abnormalities of oesophageal motility and LOS clearly suggests that the composition of the gastric juice in this context is sufficient to provoke oesophagitis. ${ }^{56}$ That the PAO level was also identified as an independent factor does not mean that patients with oesophagitis are acid hypersecretors compared with GORD patients without oesophagitis; it merely indicates that, within an individual, there is an independent increasing risk of oesophagitis relative to the PAO value. The mechanisms of increased PAO were not studied, because the pertinent factors were not assessed, in particular, Helicobacter pylori status. To the best of our knowledge, studies on gastric acid parameters and GORD related motility parameters did not establish clear relations between these parameters. ${ }^{14}$ Our study showed that PAO was not correlated with NR5 - that is, oesophageal acid clearance and basal LOS tone.

All possible oesophagitis risk factors were not evaluated, especially oesophageal mucosal resistance. ${ }^{1516}$ Oesophageal mucosal resistance, combined with oesophageal clearance, is probably one of the main factors of defence limiting the toxicity of the refluxate. It associates pre-epithelial, epithelial, and postepithelial mechanisms that currently are not 
well known. ${ }^{15} 16$ To our knowledge, no simple test evaluating oesophageal mucosal resistance, suitable for clinical studies, is available, and the respective part of oesophageal mucosal resistance among all pathophysiological factors of reflux oesophagitis has not been studied. Although oesophageal mucosal resistance and other possible oesophagitis risk factors, such as transient LOS relaxations, ${ }^{101148}$ were not evaluated, our multivariate model including NR5, LOSP, and PAO was highly discriminant because it correctly classified patients as having oesophagitis or not, in $81.3 \%$ of the cases $(95 \%$ CI, $0 \cdot 723,0.903)$. This high discrimination rate obtained with the multivariate model suggests that these three independent parameters reflect the main pathophysiological factors of reflux oesophagitis (grades 1 to 3 ).

In conclusion, this multivariate analysis confirms that reflux oesophagitis is multifactorial, with impairment of oesophageal acid clearance and basal LOSP. However, our study also showed that the level of gastric acid secretion was an independent parameter. These findings are concordant with the current knowledge of the pathophysiology of oesophagitis and need to be tested on an independent population. Furthermore, they also support the current medical therapeutic strategies - that is, gastric acid antisecretory drugs and prokinetic agents.

1 Dodds WJ, Hogan WJ, Helm JF, Dent J. Pathogenesis of reflux esophagitis. Gastroenterology 1981; 81: 376-94.

2 Richter JE, Castell DO. Gastroesophageal reflux: pathogenesis, diagnosis and therapy. Ann Intern Med 1982; 97:

3 De Caestecker JS, Heading RC. The pathophysiology of reflux. In: TPJ Hennessy, A Cuschieri, JR Bennett, eds. Reflux oesophagitis. London: Butterworths, 1989: 1-36.

4 Timmer R, Breumelhof R, Nadorp JHSM, Smout AJPM. Recent advances in the pathophysiology of gastrooesophageal reflux disease. Eur $\mathcal{F}$ Gastroenterol Hepatol 1993; 5: 485-91.

5 Kahrilas PJ. Esophageal motor activity and acid clearance. Gastroenterol Clin North Am 1990; 19: 537-50.

6 Katzka DA, DiMarino AJ. Pathophysiology of gastroesophageal reflux disease: LES incompetence and esophageal clearance. In: DO Castell, ed. The esophagus. phageal clearance. In: DO Castell,

7 Castell DO. Gastroesophageal reflux disease is a motility disorder. In: C Scarpignato, Ed. Advances in drug therapy of gastroesophageal reflux disease. Basel: Karger. Front Gastrointest Res 1992; 20: 11-6.

8 Eriksen CA, Sadek SA, Cranford C, Sutton D, Kennedy N, Cuschieri A. Reflux oesophagitis and oesophagitis transit: evidence for a primary oesophageal motor disorder. Gut 1988; 29: 448-52.

9 Sonnenberg A, Lepsien G, Müller-Lissner SA, Koelz HR, Siewart JR, Blum AL. When is esophagitis healed? Esophageal endoscopy, histology and function before and after cimetidine treatment. Dig Dis Sci 1982; 27: 297-302.

10 Dodds WJ, Dent J, Hogan WJ, Helm JF, Hauser R, Patel GK, et al. Mechanisms of gastroesophageal reflux in patients with reflux oesophagitis. $N$ Engl $f$ Med 1982; 307: 1547-52.

11 Dent J, Holloway RH, Toonli J, Dodds WJ. Mechanisms of lower oesophageal sphincter incompetence in patients with symptomatic gastro-oesophageal reflux. Gut 1988; 29: $1020-8$.

12 McCallum RW, Berkowitz DM, Levin E. Gastric emptying in patients with gastroesophageal reflux. Gastroenterology 1980; 80: 285-91.

13 Dubois A. Pathophysiology of gastroesophageal reflux disease: role of gastric factors. In: DO Castell, ed. The esophagus. Boston: Little, Brown, 1992: 479-91.

14 Cadiot G, Sékéra E, Mignon M. Gastric secretion in gastroesophageal reflux disease. In: C Scarpignato, JP Galmiche, eds. Functional evaluation in esophageal disease. Basel: Karger. Front Gastrointest Res 1994; 22:209-22

15 Goldstein JL, Schlesinger PK, Mozwecz HL, Layden TJ. Esophageal mucosal resistance: a factor in esophagitis. Gastroenterol Clin North Am 1990; 19: 565-86.

16 Orlando RC. Pathophysiology of gastroesophageal reflux disease: esophageal epithelial resistance. In: DO Castell, ed. The esophagus. Boston: Little, Brown, 1992: 463-78.

17 Little AG, DeMeester TR, Kirchner PT, O'Sullivan GC Skinner DB. Pathogenesis of esophagitis in patients with gastroesophageal reflux. Surgery 1980; 88: 101-7.
18 Baldi F, Corinaldesi R, Ferrarini F, Stanghellini V, Miglioli M, Barbara L. Gastric secretion and emptying of liquids in reflux esophagitis. Dig Dis Sci 1981; 26: 886-9.

19 Bruley des Varannes S, Touchais JY, WeberJ, Desechalliers JP, Sauger F, Denis P, et al. Oesophagite de reflux: rôles respectifs des facteurs pathogéniques oesophagiens et respectifs des facteurs pathogeniques oesophagiens. Gastroenterol Clin Biol 1986; 10: 662-8.

20 Barlow AP, DeMeester TR, Ball CS, Eypasch EP. The significance of the gastric secretory state in gastro-
esophageal reflux disease. Arch Surg 1989;124: $937-40$.

21 Hirschowitz BI. A critical analysis, with appropriate controls, of gastric acid and pepsin secretion in clinical esophagitis. Gastroenterology 1991; 101: 1149-58.

22 Zhu H, Pace F, Sangaletti O, Bianchi Porro G. Gastric acid secretion and pattern of gastroesophageal reflux in patients with esophagitis and concomitant duodenal ulcer. A multivariate analysis of pathogenetic factors. Scand $\mathcal{F}$ Gastroenterol 1993; 28: 387-92.

23 Sontag SJ, Schnell TG, Miller TQ, Nemchausky B, Serlovsky R, O'Connell S, et al. The importance of hiatal hernia in reflux esophagitis compared with lower esophageal sphincter pressure or smoking. 7 Clin Gastrophageal sphincter pressure
enterol 1991; 13: 628-43.

24 DeMeester TR, Wang CI, Wernly JA, Pellegrini CA, Little AG, Klementschitsch P, et al. Technique, indications, and clinical use of 24 hour esophageal pH monitoring. F Thorac Cardiovasc Surg 1980; 79: 656-70.

25 Ollyo JB, Fontollet CH, Monnier PH. Savary's new endoscopic grading of reflux oesophagitis: a simple, reproducible, logical, complete and useful classification. Gastroenterology 1990; 89: A100.

26 Rigaud D, Bedig G, Merrouche M, Vulpillat M, Bonfils S, Apfelbaum M. Delayed gastric emptying in anorexia nervosa is improved by completion of a renutrition program. Dig Dis Sci 1988; 33: 919-25.

27 Vatier J, Poitevin C, Mignon M. Sialic acid content and proteolytic activity in gastric juice in humans. An approach for appreciating mucus glycoprotein erosion. Dig Dis Sci 1988; 33: 144-51.

28 Vatier J, Sauvage M, Lewin M, Bonfils S. Approche d'une détermination automatique de l'activité protéolytique du suc gastrique dans les conditions de la vitesse initiale de la réaction. Biol Gastroenterol 1975; 8: 107-15.

29 Schlesinger PK, Donahue PE, Schmid B, Layden TJ. Limitations of 24-hour intraesophageal $\mathrm{pH}$ monitoring in the hospital setting. Gastroenterology 1985; 89: 797-804.

30 Pujol A, Grande L, Ros E, Pera C. Utility of inpatient 24-hour intraesophageal $\mathrm{pH}$ monitoring in diagnosis of gastroesophageal reflux. Dig Dis Sci 1988; 33: 1134-40.

31 Sekera E, Cadiot G, Poitevin C, Vallot T, Vatier J, Mignon M. Sécrétion gastrique de pepsine dans le reflux gastrooesophagien compliqué ou non d'oesophagite peptique. Gastroenterol Clin Biol 1992; 16: 141-7.

32 Bruley des Varannes S, Ravenbakht-Charifi M, Cloarec D, Pujol P, Simon J, Galmiche JP. Endobrachyoesophage et reflux gastro-oesophagien acide. Enregistrements pHmétriques étagés et étude manométrique. Gastroenterol Clin Biol 1992; 16: 406-12.

33 Parrilla P, Ortiz A, Martinez de Haro LF, Aguayo JL, Ramirez P. Evaluation of the magnitude of gastrooesophageal reflux in Barrett's oesophagus. Gut 1990; 31: 964-7.

34 Fiorucci S, Santucci L, Chiucchiu S, Morelli A. Gastric acidity and gastroesophageal reflux patterns in patients with esophagitis. Gastroenterology 1992; 103: 855-61.

35 Stanciu C, Bennett JR. Oesophageal acid clearing: one factor in the production of reflux oesophagitis. Gut 1974; 15: 852-7.

36 Williams D, Thompson DG, Marples M, Heggie L, O'Hanrahan T, Mani V, et al. Identification of an abnormal esophageal clearance response to intraluminal distension in patients with esophagitis. Gastroenterology 1992; 103: 943-53.

37 Singh P, Adamopoulos A, Taylor RH, Colin-Jones DG Oesophageal motor function before and after healing of oesophagitis. Gut 1992; 33: 1590-6.

38 Ferguson MK, Ryan JW, Little AG, Skinner DB. Esophageal emptying and acid neutralization in patients with symptoms of esophageal reflux. Ann Surg 1985; 201: 728-35.

39 DeCaestecker JS, Blackwell JN, Pryde A, Heading RC. Daytime gastro-oesophageal reflux is important in oesophagitis. Gut 1987; 28: 519-26.

40 Kahrilas PJ, Dodds WJ, Hogan WJ. Effect of peristaltic dysfunction on esophageal volume clearance. Gastroenterology 1988; 94: 73-80.

41 Tolin RD, Malmud LS, Reilley J, Fisher RS. Esophageal scintigraphy to quantitate esophageal transit (quantitation
of esophageal transit). Gastroenteroloy 1979; 76: 1402-8.

42 Orr WC, Robinson MG, Johnson LF. Acid clearance during sleep in the pathogenesis of reflux esophagitis. Dig Dis Sci 1981; 26: 423-7.

$43 \mathrm{Lin} \mathrm{S}$, Ke M, Xu J, Kahrilas PJ. Impaired esophageal emptying in reflux disease. Am $\mathcal{F}$ Gastroenterol 1994; 89: 1003-6.

44 Mittal RK, Lange RC, McCallum RW. Identification and mechanism of delayed esophageal acid clearance in subjects with hiatus hernia. Gastroenterology 1987; 92: $130-5$.

45 Sloan S, Kahrilas PJ. Impairment of esophageal emptying with hiatal hernia. Gastroenterology 1991; 100: 596-605.

46 Kahrilas PJ, Dodds WJ, Hogan WJ, Kern M, Arndorfer RC Reece A. Esophageal peristaltic dysfunction in peptic esophagitis. Gastroenterology 1986; 91: 897-904. 
47 Csendes A, Maluenda F, Braghetto I, Csendes P, Henriquez A, Quesada MS. Location of the lower oesophageal sphincter and the squamous columnar mucosal junction in 109 healthy controls and 778 patients with different degrees of endoscopic oesophagitis. Gut 1993; 34: 21-7.

48 Mittal RK, McCallum RW. Characteristics and frequency of transient relaxations of the lower esophageal sphincter of transient relaxations of the lower esophageal sphincter
in patients with reflux esophagitis. Gastroenterology 1988; in patients

49 Williams D, Thompson DG, Heggie L, O'Hanrahan T, Bancewicz J. Esophageal clearance function following treat ment of esophagitis. Gastroenterolgy 1994; 106: 108-16.

50 Collen MJ, Lewis JH, Benjamin SB. Gastric acid hypersecretion in refractory gastroesophageal reflux disease. Gastroenterology 1990; 98: 654-61.

51 Bell NJV, Hunt RH. Role of gastric acid suppression in the treatment of gastro-oesophageal reflux disease. Gut 1992; 33: 118-24.
52 Johansson KE, Tibbling L. Gastric secretion and reflux pattern in reflux oesophagitis before and during
ranitidine treatment. Scand $\mathcal{F}$ Gastroenterol 1986; 21: 487-92.

53 Jansen JBMJ, Lamers CBHW. High doses of ranitidine in patients with reflux oesophagitis. Scand $\mathcal{f}$ Gastroenterol 1990; 25 (suppl 178): 42-6.

54 Miller LS, Vinayek R, Frucht H, Gardner JD, Jensen RT, Maton PN. Reflux esophagitis in patients with Zollinger-Ellison syndrome. Gastroenterology 1990; 98: 341-6.

55 Cadiot G, Hélie C, Vallot T, Marmuse JP, Cosnes J, Riché $\mathrm{A}$, et al. Oesophagite sténosante au cours du syndrome de Zollinger-Ellison. Gastroenterol Clin Biol 1994; 18: 1018-20

56 Strader DB, Benjamin SB, Orbuch M, Lubensky TA, Gibril F, Weber C, et al. Esophageal function and occurrence of Barrett's esophagus in Zollinger-Ellison syndrome. Digestion 1995; 56: 347-56. 